\title{
Norge og Russland: sikkerhetspolitiske utfordringer i Nordområdene
}

\author{
Tormod Heier \& Anders Kjølberg (red.)
}

Oslo: Universitetsforlaget 2015

208 sider. ISBN 9788214024745

Anmeldt af Niels Bo Poulsen [PhD, centerleder ved Forsvarsakademiet, København, CFM-01@fak.dk]

Norge og Russland. Sikkerhetspolitiske utfordringer $i$ Nordområdene er - hedder det i forordet - »et bidrag til kunnskapsutviklingen (...) om Russlands rolle i internasjonal politikk, om hvordan vi skal forstå Russland, og ikke mindst hvordan vi skal møte utfordringene som dagens Russland representerer« (s.7). Til dette skal tilføjes, som antologiens titel da også gør klart, at omdrejningspunktet for bogen er det norskrussiske forhold. Dette sæt af problematikker gribes an gennem tre anslag. I publikationens del 1 er det det norsk-russiske bilaterale forhold, som belyses. Første kapitel er således en gennemgang af nordområderne i norsk sikkerhedspolitik, hvorpå følger et kapitel om russisk sikkerhedspolitisk tænkning, efterfulgt af en analyse af det norsk-russiske fiskerisamarbejde i Barentshavet. Del 2 er viet til de ydre rammevilkår, og her omhandler de tre kapitler Ruslands militære tænkning og ageren i forhold til nordområderne, hvilke militære slutninger man kan drage fra Georgien- og Ukrainekonflikterne og til Ruslands handlemuligheder i nordområderne, samt NATO's forhold til Nordområderne. Bogens del 3 sigter mod at kortlægge de indre norske rammevilkår, og det sker blandt andet i form af et kapitel om overvågnings- og efterretningsindsatsen i Nordområderne. Derpå følger kapitler om norsk maritim interessevaretagelse og om det landmilitære forsvar af Finnmark, samt om omsætningen af de militære erfaringer fra Norges deltagelse i out-of-area-operationer til forsvaret af norsk territorium.

Bogen er hovedsageligt skrevet ud fra et politologisk udgangspunkt og særligt nogle af de indledende kapitler trækker på en del teori om internationale relationer, men det er samtidig tydeligt, at bogen ikke repræsenterer en enkelt »skole« eller en samlet teoretisk tilgang til emnet Norge-Rusland. Som det påpeges i indledningen kan det norsk-russiske forhold ses som præget både af trusselsbilleder og frygt og på den anden side af samarbejde og kompromisser. Selv om flere af forfatterne opererer med en række konfliktscenarier, nogle af dem i form af en regulær militær konflikt mellem Rusland og Norge/NATO, er bogen derfor ingenlunde alarmistisk, og ansvaret for det nuværende spændte forhold mellem Rusland og »vesten « placeres i flere af kapitlerne næsten ligeligt på begge sider. 
Nogle steder bliver teksten ganske redegørende og fremstår noget refererende, men ingen af teksterne er uden analytisk dybde. Det lykkedes forfatterne ganske udmærket at dække hele spektret fra udenrigs- og sikkerhedspolitik til operative militære problemstillinger. Man mærker tydeligt, at en stor del af skribenterne har en militær baggrund, og de militært tunge kapitler er efter denne anmelders opfattelse blandt bogens bedste bidrag. Denne anmelder savnede dog flere bidrag, som undersøgte konkrete aspekter af det norsk-russiske bilaterale forhold, som supplement til det interessante kapitel om »Kompromiskulturen i Barentshavet«. Også et kapitel, som lidt mere i dybden beskrev, hvad der »gemmer sig « på den russiske side af grænsen både med hensyn til militær infrastruktur og enheder, men også med hensyn til Murmanskregionens og Kolahalvøens økonomiske, sociale og regionalpolitiske træk, kunne have passet fint ind i bogen. Bogen savner desuden et bedre kortmateriale. Kortene over Norges maritime grænser på side 132 og over Finnmark på side 158 er i forholdsvis lav opløsning, savner topografiske detaljer og kunne med fordel have suppleret med andre kort, som eksempelvis viste de vigtigste russiske baser i Nordområderne.

Redaktionelt set er der tale om en ganske vellykket publikation, hvor teksterne kun i beskeden grad overlapper, og hvor flertallet af artiklerne skriver sig opad det samme overordnede problemfelt - hvordan mødet mellem Norges og Ruslands interesser og adfærdsmønstre skal fortolkes og håndteres eller mere indirekte - men stadig to the point - bygger op til denne problemstilling. Tillige er der særdeles få fejl at finde, og sproget er letflydende, om end stedvist lidt embedsmandsagtigt.

Mens mange af kapitlerne - henset til deres snævre problemstilling - næppe vil finde mange andre læsere end specialister, er der også en række af indlæggene, som har en bredere karakter, og som utvivlsomt vil kunne finde god anvendelse i undervisningssammenhæng og ligesom de sagtens kan forstås af et bredere publikum. Samlet set er det en anbefalelsesværdig bog, som yder et væsentligt bidrag til forståelsen af Norges forhold til sin store russiske nabo. 